\title{
Determinants of Affective Behaviour for Public Service Leaders
}

\author{
Nico Schutte \\ Department of Public Administration, North-West University, Mafikeng Campus, Mmabatho, South Africa, 2745 \\ nico.schutte@nwu.ac.za
}

\section{Doi:10.5901/mjss.2014.v5n27p942}

\begin{abstract}
The changing global environment requires from public sector leaders to have specific competencies to meet pressing economic and community needs. The main objective of this research was to explore the determinants of affective competencies for leaders in the South African Public sector. A questionnaire was administered among a sample of Public sector managers $(N=168)$. The respondents perceived that public sector leaders displayed below average affective competencies relating to internalizing, organizational influencing and valuing political awareness. Significant large gaps existed between the current displays of the affective competencies versus the importance thereof. Recommendations are made.
\end{abstract}

Keywords: Public sector, strategic leaders, management, affective competencies

\section{Introduction}

The public sector did not escape the changes that came with the democratisation during the nineties and is currently in full motion: change which was brought about in the fields of technology, trade, communication and transport. All these changes contributed to a dramatic increase in the extent and complexity of South African public institutions.

Consequently, there is a greater demand on effectiveness and efficiency on the part of the public sector, which Cloete (1995) and Smit and Cronje (2000, p. 24) consider as fundamental managerial functions. Therefore, the role and function of management in the public sector in accomplishing effectiveness and efficiency in the optimal utilisation of human and material resources became increasingly significant. Fox, Schwella and Wissink (1991, p. 2) maintain that if public administration were to be limited to public management, it would pay no attention to the political nature and the dynamic and vivacious environment of public administration.

The public manager has to perform his managerial functions in this framework, and support the political party of the day in order to support value-loaded and often subjective decisions. Often it involves more than just support, and the public manager may also be expected to implement such decisions in practice. The public manager is then confronted by the reality that politics attempt to prescribe the management of a department instead of accepting the scientifically based managerial principles which should serve as a point of departure for the conduct of public managers.

The public manager cannot isolate him/herself from politics and is constantly involved with:

- Identifying of political projects to satisfy community needs.

- Interfacing and contact between the politician and the manager at this level.

- Managing projects usually performed by lower-level officials.

- Evaluating and submitting reports of subordinates to politicians for approval.

- Ensuring that recommendations, as contained in approved reports, are implemented.

- Reporting on the progress of the implementation of recommendations.

In order to implement the value-loaded political recommendations, the public manager applies scientifically based managerial principles which are independent of politics. Lower down the hierarchy officials undertake functional tasks to implement the politically motivated recommendations in practice.

In lieu of the above, the study was further designed to identify and outline the profile (task schema competencies) for public service senior managers in terms of strategic leadership competencies per competence domain, as outlined and defined by theory and depicted by Bloom (1956). Their research described the major areas of learning and thinking and classified them into three large groups called the domains of learning: a. Cognitive (thinking) b. Affective (feeling) c. Psychomotor (doing), which the new strategic leadership needs to perform successfully in their newly appointed strategic leadership positions.

The research focuses on the effective competency requirements and competency domains of all strategic leaders 
within the Public Service from Director or senior manager, Chief Director and Assistant Commissioner to top management levels (Director General). Affective competencies involve attitudes, values and emotions. The extent to which they develop these leadership competencies, will allow strategic leaders to deal with the challenges and this should contribute to their own and the institution's success. To deal with the fast social and systematic change, (public service) leaders need the interpersonal competencies included in the emotional intelligence construct: the ability to recognise and react to the emotions and feelings of other people, and the skill to help them to handle and manage their emotions Schmidt (cited in Tucker, Sojka, Barone \& McCarthy, 2000, p. 332).

Schein (1982, pp.125-7) mentions the so-called "reality shock", which often sets in when a newly appointed strategic leader realises that the actual working life is not in accordance to what he or she expected. The individual might found out that it is not only the work that is different, but might also discover that their own personal needs, values, abilities (competence) and limitations do not meet the requirements of the task. Schutte (2010) provides a synopsis of the strategic and affective leadership competencies advocated by contemporary leadership theories in Table 1 below.

Table 1: A synopsis of strategic leadership and affective competencies advocated by contemporary leadership theories

\begin{tabular}{|c|c|}
\hline Leadership Competencies & Description \\
\hline $\begin{array}{l}\text { Influence, teamwork, participation and } \\
\text { empowerment, with particular } \\
\text { emphasis on transformation and black } \\
\text { economic empowerment }\end{array}$ & $\begin{array}{l}\text { Leadership is an "influence relationship" among leaders and followers who intend real changes } \\
\text { that reflect their shared purposes. Leadership involves influence. It occurs among people, who } \\
\text { intentionally desire significant changes, and the changes reflect purpose shared by leaders and } \\
\text { followers. Influence means that the relationship among people is not passive; it is } \\
\text { multidirectional and non- coercive. }\end{array}$ \\
\hline $\begin{array}{l}\text { Ability and creativity. Challenge old } \\
\text { ways of thinking and doing }\end{array}$ & $\begin{array}{l}\text { Leadership ability determines the leader's level of effectiveness and this will influence who they } \\
\text { attract. Only self-assured leaders delegate power to others. They are problem solvers and } \\
\text { always find creative solutions to difficult problems - in a way they are pioneers in changing } \\
\text { times. }\end{array}$ \\
\hline Reciprocal & $\begin{array}{l}\text { Leadership is reciprocal. Superiors influence subordinates, but subordinates also influence } \\
\text { superiors. }\end{array}$ \\
\hline Process & $\begin{array}{l}\text { Leadership develops daily, not in a day. Leadership involves creating changes which reflects } \\
\text { purpose leaders and followers share. Leaders empower and have the ability to direct and keep } \\
\text { people focussed on their own and organisational objectives. Leaders also embrace positive } \\
\text { considerate energy and a sense of identity. }\end{array}$ \\
\hline $\begin{array}{l}\text { Navigation, recognition for } \\
\text { performance; Care, wisdom, } \\
\text { confidence, diligence and } \\
\text { communication. }\end{array}$ & $\begin{array}{l}\text { Leadership is a "people activity" and is different from administrative paperwork or planning, } \\
\text { which means that leaders need to chart the organisational course. The followers first buy into } \\
\text { the leader then into their vision. The leader acts as a strategist and has the ability to share and } \\
\text { communicate the vision and create team-learning, organisational alignment and results. }\end{array}$ \\
\hline $\begin{array}{l}\text { Respect: Honesty, integrity, openness, } \\
\text { and respect for human dignity. }\end{array}$ & $\begin{array}{l}\text { It occurs among people; it is not something done to people. Since leadership involves people, } \\
\text { there must be followers. Competent leaders know how to follow, and they set an example for } \\
\text { others. Leadership is shared among leaders and followers, with everyone fully engaged and } \\
\text { accepting higher levels of responsibility. The qualities for effective leaders are the same as } \\
\text { those needed for an effective follower. }\end{array}$ \\
\hline Inner circles & $\begin{array}{l}\text { Effective leaders are known by the people closest to them and as such, their followers think for } \\
\text { themselves and carry out assignments with energy and enthusiasm. They also develop leaders } \\
\text { amongst them. Leaders are stewards - they love and respect people, they create equal } \\
\text { opportunities and do not tolerate discrimination; they lead organisations and communities so } \\
\text { that members can learn new ways to work collaboratively. }\end{array}$ \\
\hline
\end{tabular}

Source: Schutte (2010)

\section{Research Method}

\subsection{Research Approach}

A quantitative research approach was followed using surveys to collect the data. The research was cross-sectional in nature given that the data was collected at one point in time (Field, 2009).

\subsection{Respondents}

The sample included strategic leaders that represent five major central government institutions. A total of 550 
questionnaires were administered to senior management of the five mentioned institutions. A total of 168 questionnaires were returned which represent $30.55 \%$ response rate. Most of the respondents were male (57.7\%) and representative of the black ethnic group (54.2\%). The respondents were primarily employed as directors (47\%) and with a national diploma as their highest level of qualification (32.7\%). Most of the respondents' was speaking indigenous languages (39.29\%) as their home language. The demographic characteristics of the respondents are presented in Table 2 below.

Table 2: Demographic Characteristics of the Respondents

\begin{tabular}{|c|c|c|c|}
\hline Variables & Categories & Frequency & Percentage \\
\hline \multirow[t]{3}{*}{ Gender } & Male & 97 & $57.7 \%$ \\
\hline & Female & 65 & $38.7 \%$ \\
\hline & Unknown & 6 & $3.6 \%$ \\
\hline \multirow[t]{6}{*}{ Race } & Black & 91 & $54.2 \%$ \\
\hline & White & 46 & $27.4 \%$ \\
\hline & Coloured & 8 & $4.8 \%$ \\
\hline & Indian & 15 & $8.9 \%$ \\
\hline & Other & 1 & $0.6 \%$ \\
\hline & Unknown & 7 & $4.2 \%$ \\
\hline \multirow[t]{5}{*}{ Position } & Senior Manager & 37 & $22.0 \%$ \\
\hline & Director & 79 & $47.0 \%$ \\
\hline & Commissioner & 36 & $21.4 \%$ \\
\hline & Counsellor & 10 & $6.0 \%$ \\
\hline & Unknown & 6 & $3.6 \%$ \\
\hline \multirow[t]{7}{*}{ Highest qualification } & Matric & 21 & $12.5 \%$ \\
\hline & Nat Diploma & 55 & $32.7 \%$ \\
\hline & B Degree & 25 & $14.9 \%$ \\
\hline & Honours Degree & 12 & $7.1 \%$ \\
\hline & Masters Degree & 22 & $13.1 \%$ \\
\hline & Doctoral Degree & 6 & $3.6 \%$ \\
\hline & Unknown & 27 & $16.1 \%$ \\
\hline \multirow[t]{4}{*}{ Language. } & Afrikaans & 46 & $27.4 \%$ \\
\hline & English & 27 & $16.1 \%$ \\
\hline & Indigenous & 66 & $39.29 \%$ \\
\hline & Unknown & 29 & $17.26 \%$ \\
\hline
\end{tabular}

\subsection{Measuring Instrument}

A questionnaire was developed to measure the affective competencies of the leaders. The questionnaire consists of 21 items and measure five dimensions: Communicating with flexibility, Active Participating, Political Awareness, Organising and Influencing and Internalising. A brief description of the dimensions is presented in Table 3 below.

Table 3: Description of Affective Competencies

\begin{tabular}{|l|l|}
\hline Dimension & Description \\
\hline $\begin{array}{l}\text { Communicating with } \\
\text { Flexibility }\end{array}$ & Awareness, willingness to hear, selected attention. \\
\hline Active Participating & $\begin{array}{l}\text { Active participation on the part of the strategic leader. Attends and reacts to a particular phenomenon. Job specific } \\
\text { outcomes may emphasize compliance in responding, willingness to respond, or satisfaction in responding } \\
\text { (motivation). }\end{array}$ \\
\hline Political Awareness & $\begin{array}{l}\text { This entails the reading of a group's emotional cues and power relationships. Strategic leaders need this competency } \\
\text { to recognise important social networks and to understand the forces that determine the views of clients, customers or } \\
\text { challengers. They also have the ability to correctly read situations and realities from the outside. }\end{array}$ \\
\hline $\begin{array}{l}\text { Organizing and } \\
\text { Influencing }\end{array}$ & $\begin{array}{l}\text { This competence refers to the exercising of effective strategies for persuasion. Strategic leaders need this } \\
\text { competency to influence others, they use intricate strategies like direct influence to build harmony and support, and } \\
\text { they devise dramatic events to successfully make a point. }\end{array}$ \\
\hline Internalising & \begin{tabular}{l} 
Adopt belief system and philosophy. \\
\hline
\end{tabular}
\end{tabular}


The questionnaire uses a dual scale. Respondents are first required to indicate the extent of their agreement with each statement on a five-point Lickert-type scale ranging from very dissatisfied (1) to very satisfied (5). Respondents are secondly required to indicate the importance of the talent management practices from Not Important (1) to Very Important (5).

\subsection{Statistical Analyses}

Statistical analysis was carried out using the SPSS Program (SPSS Inc, 2014). The reliability and validity of the Affective Measure was determined by means of exploratory factor analysis and Cronbach alpha coefficients. Effect sizes (Field, 2009) were used to decide on the practical significance of the findings. For purposes of this research Cohen's (1988) guidelines for the interpretation of effect sizes: 0.0099 constitutes a small effect, 0.0588 a medium effect and 0.1379 a large effect was used.

\section{Results}

Prior to factor analyses a Kaiser-Meyer-Olkin (KMO) test was done to determine the sample adequacy of the Affective Competency Scale. The Affective scale obtained a sample adequacy of 0.954 which are adequate for factor analyses (see Hair, Black, Babin \& Anderson, 2010). Exploratory factor analyses using Principal Axis Factoring analyses were done on the 21 items of the Affective competencies measure. The initial analyses showed three distinctive factors. Principal components analyses were done using Varimax rotation. The analyses resulted in three factors which explained 92.979\% of the variance. The three factors were labelled: Internalising (Factor 1), Organising Influencing (Factor 2) and Valuing Political Awareness (Factor 3). The results of the rotated factor matrix are reported in Table 4 below.

Table 4: Rotated Factor Matrix of the Affective Competency Scale

\begin{tabular}{|l|c|c|c|}
\hline & Internalising & Organising Influencing & Valuing Political Awareness \\
\hline AF1 & .661 & .499 & .460 \\
AF2 & .543 & .436 & .670 \\
AF3 & .524 & .630 & .425 \\
AF4 & .463 & .720 & .417 \\
AF5 & .586 & .612 & .478 \\
AF6 & .777 & .434 & .392 \\
AF7 & .679 & .384 & .565 \\
AF8 & .786 & .407 & .382 \\
AF9 & .347 & .676 & .606 \\
AF10 & .728 & .470 & .463 \\
AF11 & .534 & .425 & .697 \\
AF12 & .511 & .673 & .450 \\
AF13 & .741 & .464 & .416 \\
AF14 & .509 & .709 & .438 \\
AF15 & .501 & .409 & .732 \\
AF16 & .723 & .468 & .456 \\
AF17 & .399 & .558 & .667 \\
AF18 & .675 & .488 & .490 \\
AF19 & .642 & .532 & .455 \\
AF20 & .623 & .608 & .428 \\
AF21 & .601 & .677 & .314 \\
\hline
\end{tabular}

Extraction Method: Principal Axis Factoring.

Rotation Method: Varimax with Kaiser Normalization.

The descriptive statistics and reliabilities of the factors of the Affective Competency Scale are reported in Table 5 below. The results show excellent reliabilities for all three factors of the Affective Competency Measure. From the mean scores it is evident that the respondents perceived that public sector leaders displayed below average affective competencies relating to internalizing, organizational influencing and valuing political awareness. 
Table 5: Descriptive statistics and reliabilities for the Affective Competency Scale

\begin{tabular}{|l|c|c|c|c|c|}
\hline & Mean & SD & Skewness & Kurtosis & $a$ \\
\hline Affective Domain & 2.8166 & .87130 & .128 & -.283 & .981 \\
\hline Internalising & 2.6982 & .88675 & .202 & -.113 & .991 \\
\hline Organising Influencing & 2.9162 & .86489 & -.015 & -.072 & .984 \\
\hline Valuing Political Awareness & 2.8353 & .91168 & .332 & -.290 & .979 \\
\hline
\end{tabular}

In order to determine the normality of the scales obtained in the factor analysis, the Kolmogorov-Smirnov test was performed on the Affective Competency Measure, the results of which are reported in Table 6 below. This table indicates that the scale conforms to normality. The Z-statistic is 0.132 , which is greater than 0.05 , which means that the scale is normally distributed. Unlike most statistical testing, a non-significant result is sought-after here.

Table 6: One-Sample Kolmogorov-Smirnov Test

\begin{tabular}{|ll|c|}
\hline & & Affective \\
\hline $\mathrm{N}$ & & 167 \\
Normal Parametersa,b & Mean & 2.8166 \\
& Std. Deviation & .87130 \\
Most Extreme Differences & Absolute & .132 \\
& Positive & .132 \\
Kolmogorov-Smirnov Z & Negative & -.131 \\
Asymp. Sig. (2-tailed) & & .132 \\
\hline
\end{tabular}

Finally univariate analyses were performed to determine whether significant gaps exist between the current versus the importance of the dimensions of the Affective Competency Measure. The results revealed that significant gaps exist between the current demonstrations of affective competencies by business leaders versus the importance thereof. All the effects were medium. The results are reported in Table 7 below.

Table 7: Current display versus the importance of Affective Competencies

\begin{tabular}{|l|c|c|c|c|c|}
\hline & \multicolumn{2}{|c|}{ Mean } & Gap & $p$ & Eta \\
\hline Factors & Current & Importance & & & \\
\hline Affective Domain & 2.817 & 4.571 & -1.755 & .000 & .935 \\
\hline Internalising & 2.698 & 4.557 & -1.859 & .000 & .858 \\
\hline Organising and Influencing & 2.916 & 4.535 & -1.618 & .000 & .854 \\
\hline Valuing Political Awareness & 2.835 & 4.621 & -1.786 & .000 & .648 \\
\hline
\end{tabular}

\section{Discussion and Conclusion}

The main objective of this research was to explore the determinants of affective competencies for public sector leaders. The results showed that public sector leaders displayed below average affective competencies relating to internalizing, organizational influencing and valuing political awareness. The negative attitude of respondents towards the public service as experienced by them is a major concern. The assumptions can be made that there might be a communication gap between strategic leaders and other political appointed office bearers in line with proper expectations. However, the reasons leading to their negative attitude require investigation and problems in this regard need to be addressed, because they are the change agents of the public service and it will rely heavily on their input as strategic leaders.

The results further showed that strategic leaders exhibited a significantly more positive response towards the importance of the stated strategic leadership competency items for the public service than their satisfaction on the organisational performance of the stated strategic competencies. Future research should investigate why they are dissatisfied with the public service performance although they believe that the stated competency (knowledge, skills and attitude) items are very important for strategic leaders to be effective in their strategic leadership role.

In conclusion South African Public Service strategic leaders are confronted with numerous national and international challenges which required urgent and decisive action. Given these challenges and in order to achieve 
personal and public service organisational success, South African public service strategic leaders need to develop new ways of thinking or a shift of mind (paradigm shift), which will lead to improved competencies.

\section{References}

Bloom, B. S. (1956). Taxonomy of Educational Objectives. The classification of educational goals: Handbook I, cognitive domain, New York: Longman.

Cloete, J.J.N. (1995). Public Administration Glossary. Pretoria: Van Schaik Publishers.

Cohen, J. (1988). Statistical power analysis for the behavioral sciences (Revised ed.). Orlando, FL: Academic Press.

Field, A. (2009). Discovering statistics using SPSS (3rd ed.). London: Sage.

Fox, W., Schwella, E. \& Wissink, F. (1991). Public Management, Juta, Cape Town.

Schein, E.H. (1982). 'Increasing organisational effectiveness through better human resource planning and development'. In Katz, R. Career Issues in Human Resource Management. Prentice Hall , New Jersey.

Schutte, N.E. (2010). Development of a strategic leadership framework for the public service: A competence based approach. Unpublished Doctoral Dissertation: Tswane University of Technology.

Tucker, M.L., Sojka, J.Z., Barone, F.J. \& McCarthy, A.M. (2000). Training tomorrow's leaders: Enhancing the emotional intelligence of business graduates. Journal of Education for Business,75 (6), 331-337. 